\title{
Comprehension of idiomatic expressions by Russian speaking typically developing children
}

\author{
Nadezda N. Eliseeva ${ }^{a, b, *}$, Elena N. Guts ${ }^{c}$, Andrea Marinia, ${ }^{a, d}$ \\ ${ }^{a}$ Dipartimento di Lingue e Letterature, Comunicazione, Formazione e Società, University \\ of Udine, Udine, Italy \\ ${ }^{\mathrm{b}}$ Laboratory of Clinical Linguistics, Kazan Federal University, Kazan, Russia

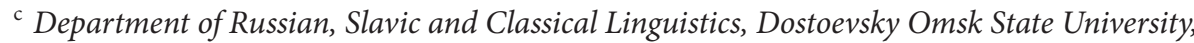 \\ Omsk, Russia \\ ${ }^{\mathrm{d}}$ Claudiana - Landesfachhochschule für Gesundheitsberufe Lorenz-Böhler-Straße, \\ Bozen, Italy \\ *Corresponding author. E-mail: eliseeva.nadezda@spes.uniud.it
}

Background. The ability to understand idiomatic expressions begins to develop at an early age. However, such skill is not achieved within the same age and at the same pace in children speaking different languages.

Objective. This study assesses comprehension of idiomatic expressions by Russian-speaking monolingual children aged 4 to 12 and monitoring the age dynamics of figurative language understanding.

Design. 80 children were split in 4 age groups balanced for gender and level of formal education. The participants were asked to identify the correct non-literal meaning of 10 idioms. For each idiomatic expression, children heard three potential interpretations (one correct, and two incorrect ones of which one was literal while the other was overtly wrong).

Results. Age-related differences were analysed by performing a series of univariate ANOVAs. These analyses showed that already at preschool age children begin to understand some kinds of idiomatic expressions and that such ability slowly develops throughout childhood. Interestingly, until the age of 6 children predominantly interpreted idioms literally. By the age of 7 their ability to correctly understand the non-literal meanings of idiomatic expressions enhanced significantly until it reached a plateau around the age of 12 .

Conclusion. The results of the study are in line with those found for children speaking other languages. The findings are interpreted in light of recent theories of language and cognitive development. Potential limitations of the study are also discussed.

Keywords: Russian language, children, language acquisition, idioms 


\section{Introduction}

According to Teliya (1996), Idiomatic expressions (IEs), just like individual words, have a nominative function and share with them features like semantic integrity and reproducibility. IEs are socially anchored and emotionally connoted (Voynova \& Molotkov, 1994). The ability to use and understand IEs likely rests on a complex array of cognitive skills, including the ability to process the semantic meaning of the single words that form the IE, the ability to inhibit the literal interpretation of the idiomatic sequence, and use of linguistic and contextual cues to select its correct indirect meaning (Coulson, 2005). It is not surprising, then, if the acquisition of this complex skill proceeds gradually during childhood and might continue until adulthood (e.g., Nippold, 2006). It has been suggested that English-speaking children with typical development begin to understand and use IEs by the age of 6 or 7 (Simms, 2007). A recent experimental study showed that the vast majority (> $90 \%$ ) of a cohort of 285 Ukrainian preschoolers (5-6 years old) who were asked to describe the figurative meaning of a list of IEs could only explain the literal meanings of the individual words that formed them (Mysan, 2016).

Unfortunately, the comprehension and production of IEs by Russian speaking children has not been systematically studied yet in developmental linguistics (Gridina, 2006). The few available studies have mostly focused on error analyses (e.g., Tseytlin, 2000) rather than on investigating how these skills develop throughout childhood and beyond. These investigations have shown that some IEs might appear far earlier than suggested by Simms (2007). For example, Piterkina (2010) and Ratajczyk (2005) showed that some highly frequent IEs might be available as early as 2 years of age. However, in these studies these indirect expressions appear quite accidentally and are not used with a figurative meaning but just as a mechanical repetition of previously heard sequences of words. This is supported by Ratajczyk (2005), who remarks that at 4-7 years old children usually understand only the literal meanings of the words that form IEs and might replace one word with another with a similar meaning.

Studies focusing on children and adolescents with developmental disorders confirm that the ability to process IEs rests on a set of cognitive skills that can be impaired. As a result, comprehension and production of IEs can often be impaired as well. For example, children older than 7 with a diagnosis of pragmatic language disorder might experience difficulties in dealing with a conversation and discourse and in the correct use of IEs (Rinaldi, 2000). These children might understand them literally, failing to interpret their indirect meanings even if they might still understand and use short phrases and words (Simms, 2007).

Some indirect evidence of the complexity of idiomatic comprehension and production comes from neuropsychological studies focusing on children with mental retardation or language impairments. For example, in Lacroix and colleagues (2010) a group of French-speaking children and adolescents with Williams'syndrome had significant difficulties in the comprehension and interpretation of IEs. This is not surprising, as these individuals often have difficulties in dealing with non-literal meanings (e.g., Karmiloff-Smith et al., 1995; Sullivan et al., 2003). Also, some children with Language Impairments (LIs) might have difficulties dealing with IEs as shown by their diminished ability to use context to understand their 
non-literal meanings on a task of Idiom comprehension (e.g., Norbury, 2004). Similarly, Spanish-speaking children with LIs aged 5 to 12 scored lower than their peers on a task aimed to assess their comprehension of figurative language (Navarrete et al., 2004). Interestingly, however, children with LIs who do not have a pragmatic disorder and have resolved their linguistic comprehension difficulties might perform like their peers with typical development on such tasks (e.g., van der Merwe and Adendorff, 2012).

The current paper aims to report the preliminary results of a larger study aimed at developing an Idiom Comprehension Task for Russian-speaking children that involves both children with Typical Development and children with Language Impairments. Namely, we present here the preliminary results obtained by administering this task to a sample of 80 monolingual children aged 4 through 11 . This study aims to determine whether the comprehension of IEs is already available at preschool-age, and to trace the development of such ability through childhood.

\section{Method}

\section{Participants}

Eighty Russian speaking children with typical development were recruited for this experiment. They formed four age groups of 20 subjects each. The groups were balanced for gender. Two of these groups consisted of 40 preschoolers aged 4 to 7 years old, whereas the remaining two groups were formed by 40 children aged 8 to 11 years old and attending primary school (see Table 1). None of the participants had any known history of speech and/or language development, mental retardation, hearing loss or pervasive developmental disorders. All participants were attending regular public schools in four different cities across Russia.

Table 1. Age, level of formal education and gender of the four groups of participants

\begin{tabular}{cccc}
\hline $\begin{array}{c}\text { Age-Group } \\
(\mathbf{N}=\mathbf{2 0} \text { per Group })\end{array}$ & Age & Education & Sex \\
\hline 1 & $4 ; 61(.49)-$ Range: $4 ; 04-5 ; 11$ & Preschoolers & $\mathrm{F}=10$ \\
2 & $6 ; 28(.43)-$ Range: $6 ; 00-7 ; 02$ & Preschoolers & $\mathrm{F}=10$ \\
3 & $8 ; 29(.43)-$ Range: $8 ; 01-9 ; 04$ & Primary School & $\mathrm{F}=13$ \\
4 & $10 ; 56(.52)-$ Range: $10 ; 01-11 ; 11$ & Primary School & $\mathrm{F}=10$ \\
\hline
\end{tabular}

\section{Materials}

A list of 40 idiomatic expressions with high frequency of occurrence in Russian was selected from the dictionary of Russian idiomatic expressions (Fedorov, 2008). Their frequency was first calculated automatically and then controlled with a survey. First, we controlled for the presence/absence of the selected IEs in the General Internet-Corpus of Russian language $\left(\mathrm{GICR}^{1}\right)$, a database which includes text data 
from Russian Internet resources. Only resources containing data from a Russian social network (VKontakte) and a blog (LiveJournal) were considered in order to check whether the selected items reflected the state-of-the-art of Russian language. News sites and Journal's Magazine Halls were not included as databases for our check due to their stylistic peculiarities. We sorted the results according to their frequency of occurrence in written texts. As a second step, we launched an online survey asking adult Russian native speakers to assess how frequently they used the selected idiomatic expressions in their daily speech or heard their friends/relatives using them. A total of 420 Russian-speaking adults aged 20 through 60 participated to this survey. They were controlled for their formal education (school / college / university / scientific degree) and profession. They assessed each IE on a threescore scale according to their daily usage (0: never; 1 : sometimes; 2 : often). Then, we compared the results of the survey with those obtained with the GICR database. As a result, the 10 idioms with the highest frequency rate were selected for the experiment. There were IEs having equivalents across several European languages with clear internal lexical meaning, such as, for example, 'похожи как две капли воды', literally translated - / like two drops of water/, which conveys the same non-literal meaning in English - 'like two peas in a pod'. The figurative meaning of such idioms might be easier for children to interpret, unlike those IEs with obscure origin, such as 'ни пуха, ни пера', literally — / not a bit of down, nor a single feather/, corresponding to an ironic wish of good luck — 'break a leg'.

\section{Procedures}

Children were tested individually in a quiet room at their schools. Participants were asked to identify the correct non-literal meaning of a list of 10 IEs that were uttered with a flat tone and a normal speech rate by the examiner. For each item children heard three potential interpretations (one correct, one literal, and one overtly wrong) and were asked to choose the one that they thought to be correct. In case of missing (after 10 seconds) or a wrong response (i.e., literal or completely wrong) they scored 0 . If they provided the right answer they scored 1 , for a maximum total score of 10 .

\section{Results}

Potential age-related differences in the ability to identify the correct indirect meaning of the provided IEs were explored, running one univariate ANOVA, with the age-group ( 4 to 11 ) as independent variable, and the total score obtained by each age-group at this task as dependent variable. Alpha level was set at $\mathrm{p}<.05$ (see Table 2).

The ANOVA showed the presence of a significant age effect on the ability of the four groups to produce correct answers on the task $([\mathrm{F}(3,79)=26.076 ; \mathrm{p}<.001])$. Specific group-related relations were further explored by performing post-hoc Tukey's tests. The post-hoc analyses showed the absence of group-related differences among preschoolers (Group 1 vs Group 2, $\mathrm{p}=.135$ ) and also among school-aged children (Group 3 vs Group 4, p=.997). However, preschoolers performed significantly worse than older children: Groups 1 and 2 vs. Groups 3 and 4: all ps<.001). 
Table 2. Performance of the four groups of participants on the Comprehension of Idiomatic Expressions' Task. Data are expressed as means (and standard deviations)

\begin{tabular}{cccc}
\hline Age-Group & Correct Answers & Literal Answers & Wrong Answers \\
\hline 1 & $2.6(2.30)$ & $3.45(1.57)$ & $2.85(1.79)$ \\
2 & $4.2(2.21)$ & $3(2.49)$ & $1.9(1.12)$ \\
3 & $7.75(1.94)$ & $0.9(1.17)$ & $1.3(1.45)$ \\
4 & $7.9(2.71)$ & $0.9(1.17)$ & $0.6(.82)$ \\
\hline
\end{tabular}

The Levene's test for homogeneity of variance was significant for literal and wrong answers $(\mathrm{ps}<.001)$. For this reason, non-parametric analyses (i.e., KruskalWallis test for independent samples) were run to explore group-related differences on these two variables. As for the production of literal answers, a group-related difference was found: $\left(X^{2}(3)=29.676 ; p<.001\right)$. The pairwise comparisons showed that no significant differences were found between the two preschool-age groups $(\mathrm{p}=.999)$ nor among the two groups of children attending primary school $(\mathrm{p}=.999)$. However, kindergarten children and primary school students did differ among each other (Group 1 vs Group 3: $<<.001$; Group 1 vs Group 4: $\mathrm{p}<.001$; and Group 2 vs Group 3: $\mathrm{p}<.014$; Group 2 vs Group 4: $\mathrm{p}<.012$ ).

A group-related difference was found also for the production of wrong answers $\left(\mathrm{X}^{2}(3)=23.957 ; \mathrm{p}<.001\right)$. Again, the pairwise comparisons showed that no significant differences were found between the two preschool-age groups $(\mathrm{p}=.999)$ nor among the two groups of children attending primary school $(\mathrm{p}=.719)$. However, kindergarten children and primary school students did differ among each other (Group 1 vs Group 3: p<.016; Group 1 vs Group 4: $\mathrm{p}<.001$; Group 2 vs Group 4: $\mathrm{p}<.005)$ with the only notable exception of the performance of children in Groups 2 and 3 that was no different on this variable ( $\mathrm{p}=.462)$.

Overall, these results suggest that the ability to process the non-literal meaning of IEs is still not mature until the age of 6, begins to be functional around the age of 7 , and continues maturing until the age of 9 . After this age, it remains somehow stable at least until the age of 11 .

\section{Discussion}

The acquisition of IEs occurs gradually and develops across childhood and adolescence. Some IEs might be acquired intuitively, relying on context, while others are acquired during a process of formal learning. The current literature shows that the performance on tasks assessing comprehension and production of IEs in children improves as a function of increasing age (e.g., Nippold, Taylor \& Baker, 1996; Hsieh \& Hsu, 2010). The results of studies using different procedures for the assessment of IE comprehension in participants speaking different languages suggest that by the age of 7 years old children are able to process IEs by focusing on the literal meaning of the words they are made of. Indeed, it has been suggested that until 6 years of age, children might predominantly use a word-by-word analysis strategy while processing figurative language (e.g. Levorato and Cacciari, 1995). 
The results from the current study suggest that monolingual children with typical development can process some IEs already at pre-school age, but tend to split them into individual words and interpret them literally: up to age 7 they were able to produce approximately $40 \%$ of correct responses, with $30 \%$ of literal responses. On the other hand, these data also suggest that the first key age when children significantly improve their comprehension of figurative language is around 7-8 years. By the age of 12 children were able to provide a correct response, on average, in 8 out of 10 cases, therefore almost reaching ceiling level. A similar trend had been previously noted by Levorato and Cacciari (1995) for Italian-speaking children. Considering that some recent studies failed to find any age-related difference in adults older than 20 years in understanding idioms (e.g., Hung and Nippold, 2014), it is likely that the process of acquisition of IEs further develops slowly from 12 to late adolescence before reaching full maturation.

A relevant question that still needs to be answered concerns the potential reasons for the age-related differences in the ability to process IEs found in this and previous studies. A potential explanation might stem from the types of IEs children were required to understand. IEs differ on several dimensions, and the degree of difficulty of their understanding might vary accordingly (Titone \& Connine, 1994; Libben \& Titone, 2008). As to this issue, the available evidence is quite controversial. For example, Nippold and colleagues suggest that decompositional idioms might be easier to understand than those with low decompositional ratings (Nippold \& Duthie, 2003; Nippold \& Rudzinski, 1993). In contrast, a more recent study by Whyte and colleagues (2014) highlights the role of social contextual cues. In our study, we controlled for the familiarity of the selected IEs. However, because of the absence of descriptive norms of compositionability, predictability and literability for Russian IEs, we could not control also for these potentially confounding variables. Nonetheless, a literature review suggests that some environmental (i.e., academic skills), cognitive and even biological factors might allow us to interpret our findings. For example, it has been shown that academic learning might significantly affect the ability to understand and correctly use IEs. In order to examine the relationship between academic competence and IEs comprehension, Caillies and Le Sourn-Bissaoui's (2006) assessed the performance of a large cohort of 116 Frenchspeaking children with TLD aged 4 to 9 on an IE comprehension task. They found a significant correlation between reading level and the ability to correctly interpret the figurative meaning of idioms. Similar findings have also been reported in other investigations focusing on children with different languages (e.g., Levorato, Nesi \& Cacciari, 2004; Cain \& Towse, 2008). However, reading skills alone might not fully explain why older children perform better on such tasks. It is likely that the overall linguistic maturation enhanced by scholarization exerts a positive effect on this complex ability. For example, several studies found significant correlations between the ability to correctly process IEs and the maturation of metalinguistic skills in children aged 6 to 10 (e.g., Bernicot, Laval and Chaminaud, 2007), the development of their grammatical skills and lexical repertoire (e.g., Norbury, 2004), as well as their ability to use semantic analysis and contextual cues to understand them (e.g., Cain, Towse \& Knight, 2009).

Apparently, not only environmental factors but also cognitive and biological factors might play a key role in enhancing the children's ability to process IEs. 
As figurative language is supposedly more demanding than understanding literal meanings (e.g. Proverbio et al., 2009; Coulson \& Van Petten, 2007), some cognitive skills might play a key role in such a process, and this might determine the difficulty to properly understand IEs until the cognitive system has reached an adequate level of maturation (likely by the age of 6 to 8 years, as proposed by Caillies and Le Sourn-Bissaoui, 2013). This hypothesis is apparently also supported by the available functional neuroimaging evidence which suggests that idiom comprehension is implemented in an extensive neural network, including bilateral inferior frontal and middle temporal gyri, left cerebellum, right insula and left lingual gyrus in the posterior temporal areas (e.g., Oliveri, Romero \& Papagno, 2004; Huber-Okrainec, Blaser \& Dennis, 2005; Zempleni et al., 2007; but see also Bohrn, Altmann \& Jacobs [2012] for a review). It is therefore likely that idiom comprehension involves several cognitive processes, such as executive functions (i.e., inhibition) and working memory skills (e.g., Gernsbacher \& Robertson, 1999; Qualls \& Harris, 2003; Fogliata et al., 2007; Caillies \& Le Sourn-Bissaoui, 2013) that mature slowly during childhood. This biological constraint is likely at the origin of the slow development of idiom comprehension in children and the direct relation between cognitive development, and idiomatic comprehension skills on large samples of children should be the target of future research.

\section{Conclusion}

The findings of the current study contribute to our understanding of how the ability to correctly comprehend IEs develops through childhood and which factors might affect idiom understanding. First, we showed that already by the age of 4 Russian-speaking children can understand some IEs but still have problems in correctly interpreting the nonliteral meanings of the majority of the items. Second, the results of the current experiment are in line with those from studies with children of the same age speaking other languages, and support the hypothesis of a great developmental change which takes place around 7-8 years old and can be explained by a complex effect of cognitive (internal) and environmental (external) factors. Unfortunately, one limitation of this study is that we did not control for these variables. Future studies should take these aspects into account in order to determine the exact role of such factors on idiom comprehension. Third, our study documented a ceiling effect in children at around 11 years of age. Such effect might be explained in part by the rapid development of their academic competence. In order to determine at what age the process of idiom comprehension reaches full maturation, future studies should investigate whether these skills further develop into adolescence in large longitudinal cohorts of participants.

\section{Acknowledgments}

The study was performed according to the Russian Government Program of Competitive Growth of Kazan Federal University and was supported by a grant from Erasmus Mundus Action 2 Program ("International Academic Mobility Network with Russia - IAMONET-RU” project) to N.E. and by the Russian Foundation for Humanities, project No. 15-04-00325a "Childhood in the discursive space of the 
region: A comprehensive analysis of the institutional and personal communications involving a child". The authors are grateful to Professor Kelly Wager for her kind assistance.

\section{References}

Bernicot, J., Laval, V., \& Chaminaud, S. (2007). Nonliteral language forms in children: In what order are they acquired in pragmatics and metapragmatics? Journal of Pragmatics, 39(12), 2115-2132. doi: 10.1016/j.pragma.2007.05.009

Bohrn, I.C., Altmann, U., \& Jacobs, A.M. (2012). Looking at the brains behind figurative language. A quantitative meta-analysis of neuroimaging studies on metaphor, idiom, and irony processing. Neuropsychologia, 50(11), 2669-2683. doi: 10.1016/j.neuropsychologia.2012.07.021

Cain, K., \& Towse, A.S. (2008). To get hold of the wrong end of the stick: Reasons for poor idiom understanding in children with reading comprehension difficulties. Journal of Speech, Language, and Hearing Research, 51(6), 1538-1549. doi: 10.1044/1092-4388(2008/07-0269)

Cain, K., Towse, A.S., \& Knight, R.S. (2009). The development of idiom comprehension: An investigation of semantic and contextual processing skills. Journal of Experimental Child Psychology, 102(3), 280-298. doi: 10.1016/j.jecp.2008.08.001

Coulson, S. (2005). The literal/nonliteral distinction. In S. Coulson and B. Lewandowska- Tomaszczyk (Eds.), The literal and the nonliteral in language and thought (pp. 9-22). Berlin: Peter Lang.

Coulson, S., \& Van Petten, C. (2007). A special role for the right hemisphere in metaphor comprehension?: ERP evidence from hemifield presentation. Brain Research, 1146, 128-145. doi: 10.1016/j.brainres.2007.03.008

Caillies, S., \& Le Sourn-Bissaoui, S. (2006). Idiom comprehension in French children: A cock-and-bull story. European Journal of Developmental Psychology, 3(2), 189-206. doi: 10.1080/17405620500412325

Caillies, S., \& Le Sourn-Bissaoui, S. (2013). Nondecomposable idiom understanding in children: Recursive theory of mind and working memory. Canadian Journal of Experimental Psychology/Revue canadienne de psychologie expérimentale, 67(2), 108.

Fogliata, A., Rizzo, S., Reati, F., Miniussi, C., Oliveri, M., \& Papagno, C. (2007). The time course of idiom processing. Neuropsychologia, 45(14), 3215-3222. doi: 10.1016/j.neuropsychologia.2007.06.009

Gernsbacher, M.A., \& Robertson, R.W. (1999). The role of suppression in figurative language comprehension. Journal of Pragmatics, 31(12), 1619-1630. doi: 10.1016/S0378-2166(99)00007-7

Gridina, T.A. (2006). Mehanizmy reinterpretacii i obrazovanija frazeologizmov $v$ detskoj rechi Russkij jazyk: sistema i funkcionirovanie ( $k$ 80-letiju professora P. P. Shuby) [Mechanisms of representation and development of idioms in child speech in Russian: The system and its functioning]. Paper presented at III International scientific conference, April 6-7, Minsk, Belorus.

Hsieh, S.C., \& Hsu, C.C. (2010). Idiom comprehension in Mandarin-speaking children. Journal of Psycholinguistic Research, 39(6), 505-522. doi: 10.1007/s10936-009-9145-z

Huber-Okrainec, J., Blaser, S.E., \& Dennis, M. (2005). Idiom comprehension deficits in relation to corpus callosum agenesis and hypoplasia in children with spina bifida meningomyelocele. Brain and Language, 93(3), 349-368. doi: 10.1016/j.bandl.2004.11.002

Hung, P.F., \& Nippold, M.A. (2014). Idiom understanding in adulthood: Examining age-related differences. Clinical Linguistics \& Phonetics, 28(3), 208-221. doi: 10.3109/02699206. 2013.850117 
Karmiloff-Smith, A., Klima, E., Bellugi, U., Grant, J., \& Baron-Cohen, S. (1995). Is there a social module? Language, face processing, and theory of mind in individuals with Williams syndrome. Journal of Cognitive Neuroscience, 7, 196-208. doi: 10.1162/jocn.1995.7.2.196

Lacroix, A., Aguert, M., Dardier, V., Stojanovik, V., \& Laval, V. (2010). Idiom comprehension in French-speaking children and adolescents with Williams' syndrome. Research in Developmental Disabilities, 31(2), 608-616. doi: 10.1016/j.ridd.2009.12.011

Levorato, M.C., \& Cacciari, C. (1995). The effect of different tasks on the comprehension and production of idioms in children. Journal of Experimental Child Psychology, 60, 261-283. doi: 10.1006/jecp.1995.1041

Levorato, M.C., Nesi, B., \& Cacciari, C. (2004). Reading comprehension and understanding idiomatic expressions: A developmental study. Brain and Language, 91(3), 303-314. doi: 10.1016/j.bandl.2004.04.002

Libben, M.R., \& Titone, D.A. (2008). The multidetermined nature of idiom processing. Memory \& Cognition, 36(6), 1103-1121. doi: 10.3758/MC.36.6.1103

Mysan, I.V. (2016). Psiholingvisticheskie osobennosti ponimanija detmi starshego doshkolnogo vozrasta frazeologizmov [Psychological aspects of understanding idioms in senior preschoolers]. Paper presented at VII International seminar Doshkolnoe obrazovanie: opyt, problemy, perspektivy [Preschool education: Experience, issues, perspectives], March 2425, Baranovichi, Belorus.

Buiza Navarrete, J.J., Adrián Torres, J.A., González Sánchez, M., \& Rodríguez-Parra, M.J. (2004). Evaluación de marcadores psicolingüísticos en el diagnóstico de niños con trastorno específico del lenguaje. Revista de Logopedia, Foniatría y Audiología, 24(4), 142-155. doi: 10.1016/S0214-4603(04)75797-6

Nippold, M.A. (2006). Language development in school-age children, adolescents and adults. In K. Brown (Ed.), Encyclopedia of Language and Linguistics (2 ${ }^{\text {nd }}$ ed., Vol. 6, pp. 368-372). Oxford, UK: Elsevier Publishing.

Nippold, M.A., \& Duthie, J.K. (2003). Mental imagery and idiom comprehension: A comparison of school-age children and adults. Journal of Speech, Language, and Hearing Research, 46(4), 788-799. doi: 10.1044/1092-4388(2003/062)

Nippold, M.A., \& Rudzinski, M. (1993). Familiarity and transparency in idiom explanation. A developmental study of children and adolescents. Journal of Speech and Hearing Research, 36, 728-737. doi: 10.1044/jshr.3604.728

Nippold, M.A., Taylor, C.L., \& Baker, J.M. (1996). Idiom understanding in Australian youth: A Cross-cultural comparison. Journal of Speech, Language, and Hearing Research, 39(2), 442-447. doi: 10.1044/jshr.3902.442

Norbury, C.F. (2004). Factors supporting idiom comprehension in children with communication disorders. Journal of Speech, Language, and Hearing Research, 47(5), 1179-1193. doi: $10.1044 / 1092-4388(2004 / 087)$

Oliveri, M., Romero, L., \& Papagno, C. (2004). Left but not right temporal involvement in opaque idiom comprehension: A repetitive transcranial magnetic stimulation study. Journal of Cognitive Neuroscience, 16(5), 848-855. doi: 10.1162/089892904970717

Piterkina, Ju.S. (2010). Frazeologizmy v detskoj rechi [Phraseologisms in children's speech]. Izvestija Rossijskogo gosudarstvennogo pedagogicheskogo universiteta im. A.I. Gercena [Gertzen Russian State University Bulletin], 108.

Proverbio, A.M., Crotti, N., Zani, A., \& Adorni, R. (2009). The role of left and right hemispheres in the comprehension of idiomatic language: An electrical neuroimaging study. $B M C$ Neuroscience, 10(1), 1. doi: 10.1186/1471-2202-10-116

Qualls, C.D., \& Harris, J.L. (2003). Age, working memory, figurative language type, and reading ability influencing factors in African American adults' comprehension of figurative lan- 
guage. American Journal of Speech-Language Pathology, 12(1), 92-102. doi: 10.1044/10580360(2003/055)

Ratajczyk, K. (2009). Otnositelno “vozrastnoj” harakteristiki ispolzovanija frazeologizmov v rechi detej (na materiale russkogo jazyka) [On age-dependent characteristics of idiom use in children (Russian-speaking children taken as an example)]. Acta Universitatis Lodziensis. Folia Linguistica Rossica, 5, 165-174.

Simms, M.D. (2007). Language disorders in children: Classification and clinical syndromes. Pediatric Clinics of North America, 54(3), 437-467. doi: 10.1016/j.pcl.2007.02.014

Sullivan, K., Winner, E., \& Tager-Flusberg, H. (2003). Can adolescents with Williams syndrome tell the difference between lies and jokes? Developmental Neuropsychology, 23(1-2), 85-103. doi: 10.1080/87565641.2003.9651888

Teliya, V.N. (1996). Russkaya frazeologiya: Semanticheskiy, pragmaticheskiy i lingvo-kulturologicheskiy aspekty [Russian phraseology: Semantic, pragmatic and cultorological aspects]. Moscow: Yazyiki Russkoy Kulturyi.

Titone, D.A., \& Connine, C.M. (1994). Descriptive norms for 171 idiomatic expressions: Familiarity, compositionality, predictability, and literality. Metaphor and Symbol, 9(4), 247-270. doi: 10.1207/s15327868ms0904_1

Tseytlin, S.N. (2000). Yazyik i rebenok: Lingvistika detskoy rechi: uchebnoye posobie dlya studentov vyisshih uchebnykh zavedeniy [Language and child: Linguistics of child speech. Handbook for university students]. Moscow: VLADOS.

Fedorov, A.I. (2008). Frazeologicheskij slovar russkogo literaturnogo jazyka: okolo 13000 frazeologicheskih edinic [Russian phraseological dictionary: Approximately 13,000 phraseological items]. Moscow: AST.

van der Merwe, K., \& Adendorff, R.D. (2012). Comprehension and production of figurative language by Afrikaans-speaking children with and without specific language impairment. Southern African Linguistics and Applied Language Studies, 30(1), 39-63. doi: $10.2989 / 16073614.2012 .693708$

Voynova, L.A., \& Molotkov, A.I. (1994). Frazeologicheskiy slovar russkogo yazyika [Russian phraseological dictionary]. Moscow: Variant.

Whyte, E.M., Nelson, K.E., \& Scherf, K.S. (2014). Idiom, syntax, and advanced theory of mind abilities in children with autism spectrum disorders. Journal of Speech, Language, and Hearing Research, 57(1), 120-130. 10.1044/1092-4388(2013/12-0308)

Zempleni, M.Z., Haverkort, M., Renken, R., \& Stowe, L.A. (2007). Evidence for bilateral involvement in idiom comprehension: An fMRI study. Neuroimage, 34(3), 1280-1291. doi: 10.1016/j.neuroimage.2006.09.049

Original manuscript received April 20, 2017

Revised manuscript accepted October 9, 2017

First published online November 30, 2017 


\section{Appendix}

A list of idiomatic expressions used in the study

1. V odno uho vletelo, v drugoe - vyletelo (Rusian - В одно ухо влетело, в другое вылетело);

2. Ni puha ni pera (Russian - Ни пуха, ни пера);

3. Bezhat' slomya golovu (Russian - Бежать сломя голову);

4. Schitat' voron (Russian - Считать ворон);

5. Glaza razbezhalis' (Russian - Глаза разбежались);

6. Hodit' po pyatam (Russian - Ходить по пятам);

7. Ushi razvesit' (Russian - Уши развесить);

8. Muhi ne obidit (Russian - Мухи не обидит);

9. Dusha v pyatki ushla (Russian - Душа в пятки ушла);

10. Kak dve kapli vody (Russian - Как две капли воды). 